\section{Nauplius}

The Journal of The

Brazilian Crustacean Society

e-ISSN 2358-2936

www.scielo.br/nau www.crustacea.org.br
This article is part of the tribute offered

by the Brazilian Crustacean Society

in memoriam of Michael Türkay for his

\title{
Expanding diversity in the mantis shrimps: two new genera from the eastern and western Pacific (Crustacea: Stomatopoda: Squillidae)
}

\author{
Cara Van Der Wall, ${ }^{1,2}$ and Shane T. Ahyong ${ }^{2,3}$ \\ 'School of Life and Environmental Sciences, University of Sydney, Sydney, NSW 2006, \\ Australia. \\ ${ }^{2}$ Australian Museum Research Institute, Australian Museum, 1 William St, Sydney, \\ NSW 2010, Australia. \\ ${ }^{3}$ School of Biological, Earth and Environmental Sciences, University of New South \\ Wales, Kensington, NSW 2052, Australia.
}

ZOOBANK http://zoobank.org/urn:lsid:zoobank.org:pub:628E09EA-CA9F-48EEAE8A-CA48061AE283

\section{Abstract}

Squillidae is the largest family in the Stomatopoda, with 47 genera to date. Phylogenetic analyses have shown Squilla Fabricius, 1787 and Oratosquilla Manning, 1968 to be para- or polyphyletic. Two poorly documented species within these genera, Squilla parva Bigelow, 1891 (eastern Pacific) and Oratosquilla kempi (Schmitt, 1931) (western Pacific) are not closely related to the respective type species of the genera in which they are currently placed. We herein redescribe S. parva and O. kempi based on type and other material, and propose two new genera for their reception, increasing the

CORRESPONDING AUTHOR Shane T. Ahyong shane.ahyong@austmus.gov.au SUBMITTED 19 December 2016 ACCEPTED 10 February 2017 PUBLISHED 8 MaY 2017

Guest Editor

Célio Magalhães

DOI 10.1590/2358-2936e2017012 number of squillid genera to 49 .

\section{KEY WORDS}

Squilloidea, new genus, mantis shrimp, Indo-West Pacific, Atlanto-East Pacific. 


\section{INTRODUCTION}

Until the latter half of the $20^{\text {th }}$ century, most species of Stomatopoda were included in the genus Squilla Fabricius, 1787, family Squillidae Latreille, 1802. In a major revision of Squillidae, Manning (1968) restricted the genus Squilla to species occurring in the AtlantoEast Pacific regions and erected numerous new genera to accommodate the Indo-West Pacific species as well as several Atlanto-East Pacific species. Significant subsequent revisions to Squillidae have recognized a total of 47 genera to date (Manning and Camp, 1983; Manning, 1995; Manning and Heard, 1997; Ahyong, 2001; 2013). Comprehensive phylogenetic analyses of the Squillidae recognized several generic groups within the family (Ahyong, 2005) and corroborated speculation by Manning and Camp (1983) and Manning and Heard (1997) in finding the Atlanto-East Pacific genus Squilla (as restricted by Manning, 1968) to be polyphyletic, and identified further polyphyly in the genus Oratosquilla Manning, 1968. Among these, two species that have often been mentioned in literature but which are poorly documented taxonomically were found not to be closely related to the respective type species of their assigned genera: Squilla parva Bigelow, 1891 (eastern Pacific) was found to lie outside the primary Squilla group (that including the type species, Squilla mantis Linnaeus, 1758), and Oratosquilla kempi (Schmitt, 1931) (western Pacific) was found to be distantly removed from other species of Oratosquilla. Although both Squilla and Oratosquilla are subject to further ongoing study, we herein redescribe S. parva and $O$. kempi based on type and other material, and propose two new genera for their reception, increasing the number of squillid genera to 49 .

\section{Material and Methods}

Morphological terminology and size descriptors follow Ahyong $(2001 ; 2012)$. Total length (TL) is measured along the dorsal midline from the tip of the rostral plate to the apices of the submedian teeth of the telson. Carapace length $(\mathrm{CL})$ is measured along the dorsal midline and excludes the rostral plate. The corneal index (CI) is given as $100 \mathrm{CL} /$ cornea width. Specimens are deposited in the Australian Museum, Sydney (AM); the Florida Museum of Natural History, Gainesville (FLMNH); the National Museum of
Natural History, Smithsonian Institution, Washington D.C. (USNM); and the National Taiwan Ocean University, Keelung (NTOU).

\section{Systematics}

\section{Superfamily Squilloidea Latreille, 1802}

Family Squillidae Latreille, 1802

\section{Michalisquilla n. gen.}

Diagnosis. Dorsal integument finely pitted. Eye large, cornea bilobed. Ophthalmic somite anterior margin emarginate. Ocular scales separate. Carapace with anterolateral spines; median, intermediate, lateral, marginal and reflected marginal carinae present; median carina lacking branches of anterior bifurcation; lower posterolateral margin without obtuse angle. Mandibular palp absent or 1-3 articulate. Maxillipeds $1-5$ each with epipod. Raptorial claw dactylus with 6 teeth; carpus with undivided dorsal carina; propodus unarmed distally; merus lacking outer inferodistal spine. Thoracic somite 5 lateral process a blunt diagonal projection, with small ventral spine. Thoracic somites 6-7 lateral processes triangular, faintly bilobed; anterior lobe considerably smaller than posterior lobe. Hook process of petasma apically blunt, longer than tube process. Abdominal somites 1-5 with distinct submedian, intermediate, lateral and marginal carinae; somite 6 with submedian, intermediate and lateral carinae. Telson with prelateral lobe; mid-dorsal surface with curved rows of pits; submedian teeth with fixed apices; postanal carina absent. Uropodal protopod with one lobe between terminal spines; inner margin crenulate.

Type species. Squilla parva Bigelow, 1891, by present designation and monotypy.

Etymology. Derived from the combination of the Greek for Michael (Mixád $\eta \zeta$ ) and the generic name Squilla, in honour of the late Michael Türkay for his career long contributions to carcinology. Gender feminine.

Remarks. Ahyong (2005) showed S. parva to lie outside of Squilla sensu stricto, being probably more 
closely related to Gibbesia Manning and Heard, 1997. The presence of six rather than five teeth on the dactylus of the raptorial claw, the short and blunt rather than strongly produced lateral process of thoracic somite 5 , and the blunt rather than spinular apex of the hook process of the male petasma, however, exclude S. parva from Gibbesia, justifying its removal to the new genus Michalisquilla. Michalisquilla parva n. comb. shares with species of Squilla a distinctly bilobed cornea, a unilobate lateral process of thoracic somite 5 and fixed submedian teeth on the telson. Michalisquilla, however, differs from Squilla as now restricted, in having the posterior lobe of the lateral process of thoracic somite 5 produced to a short, diagonal projection instead of a prominent lateral or anterolaterally produced spine, and a rounded instead of angular posterolateral margin of the carapace. Additionally, the hook process of the petasma is blunt in Michalisquilla instead of being produced to an apical spine, and the hook process of the petasma is markedly longer than, instead of about as long the tube process. Furthermore, Michalisquilla is the only squilloid in the Atlanto-East Pacific with variable segmentation of the mandibular palp, which may be absent or composed of 1-3 articles in adults. All species of Squilla, as well as all other Atlantic squilloids bear an apical spine on the hook process of the petasma, and lack variation in the condition of the mandibular palp. Crenatosquilla oculinova (Glassell, 1942) is the only other eastern Pacific squillid with an apically blunt process on the petasma, but it differs in numerous diagnostic features and is phylogenetically distant, as a member of the Meiosquilla Group, rather than Squilla Group (Ahyong, 2005).

Although further revision of Squilla is required, the removal of S. parva to Michalisquilla renders Squilla homogeneous for the major diagnostic features of a distally pointed hook process of the endopod of male pleopod 1, presence of a 3-articulate mandibular palp, and the lateral process of thoracic somite 5 as a single prominent anterolaterally produced spine.

\section{Michalisquilla parva (Bigelow, 1891) n. comb.}

$$
\text { (Fig. 1, 3A) }
$$

Squilla parva Bigelow, 1891: 274; 1894: 518-520, figs. 11-12. — Schmitt, 1940: 168-169, fig. 14. — Manning, 1968: 126. — Manning, 1972a: 101, 104, tab. 1, 2. - Manning, 1972b: 306. - Manning, 1974: 109. — Reaka and Manning, 1980: 6. — Manning and Camp, 1983: 322. - Hendrickx, 1984: 274. - Hendrickx and Salgado-Barragán, 1989: 246, tab. 1. - Hendrickx and SalgadoBarragán, 1991: 80,97, 119-121, 132, 136, 137, 138, $139,149,155,159,162$, 163, figs. 69, 70, 73, 78, pl. 28, tab. 26, 27. - Hendrickx and Salgado-Barragán, 1994: 225, tab. 1. - Hendrickx and VázquezCureño, 1998: tab. 1. - Hendrickx and SalgadoBarragán, 2002: 392, 398. - Murillo-Bohórquez and Alvarez-León, 2004: 6. - Hendrickx, 2005: 33, 34 tab. 1-3.

Type material. LECTOTYPE: USNM 18479, male (TL $40 \mathrm{~mm}$ ), Bay of Panama, $8^{\circ} 38^{\prime} 00^{\prime} \mathrm{N}$ 79³1'30”W, 29 m, Albatross Stn 2802, 30 March 1888. PARALECTOTYPES: USNM 18477, 1 male (TL 39 $\mathrm{mm}$ ), 3 juvenile males (TL 31-36 mm), Bay of Panama, 8 51'00”N 79³1'30”'W, 13 m, Albatross Stn 2800, 30 March 1888; USNM 18478, 1 female (TL 35 mm), Bay of Panama, 847’00”N 79²9'30”'W, 26 m, Albatross Stn 2801, 30 March 1888; USNM 124777, 1 male (TL 34 mm), Bay of Panama, 8³8’00”N 79³1’30”W, 29 m, Albatross Stn 2802, 30 March 1888.

Other material examined. FLMNH UF 19464, 1 male (TL $44 \mathrm{~mm}$ ), Taboga Island, Panama, 10-15 $\mathrm{m}$, sand-mud bottom, dredge, PAN-025, Anker-027, RV Urraca, 8 February 2007; USNM 150744, 1 male (TL $51 \mathrm{~mm}$ ), 1 female (TL $47 \mathrm{~mm}$ ), Venado Beach, Panama Bay, Panama, Canal Zone, $8^{\circ} 54^{\prime} \mathrm{N} 79^{\circ} 35^{\prime} \mathrm{W}$, on sandbar to Isla Venado, intertidal, poison, coll. C.E. Dawson, 4 April 1973; USNM 1277719, 15 males (TL 38-77 mm), 12 females (TL 40-60 mm), E of Chitre, Gulf of Panama, $7^{\circ} 51.102$ 'N 80¹4.202'W, 20 m, RV Pilsbury P-491, 2 May 1967.

Description. Dorsal integument weakly pitted.

Eye extending to end of or slightly beyond antennular peduncle article 1; cornea strongly bilobed, set slightly obliquely on stalk; CI 377-499. Ophthalmic somite anterior margin medially emarginate. Ocular scales truncate, separate.

Antennular peduncle length 0.90-0.98CL. Antennular somite dorsal processes trianguloid, directed anterolaterally, apices blunt. Antennal scale length $0.44-0.48 \mathrm{CL}$. 


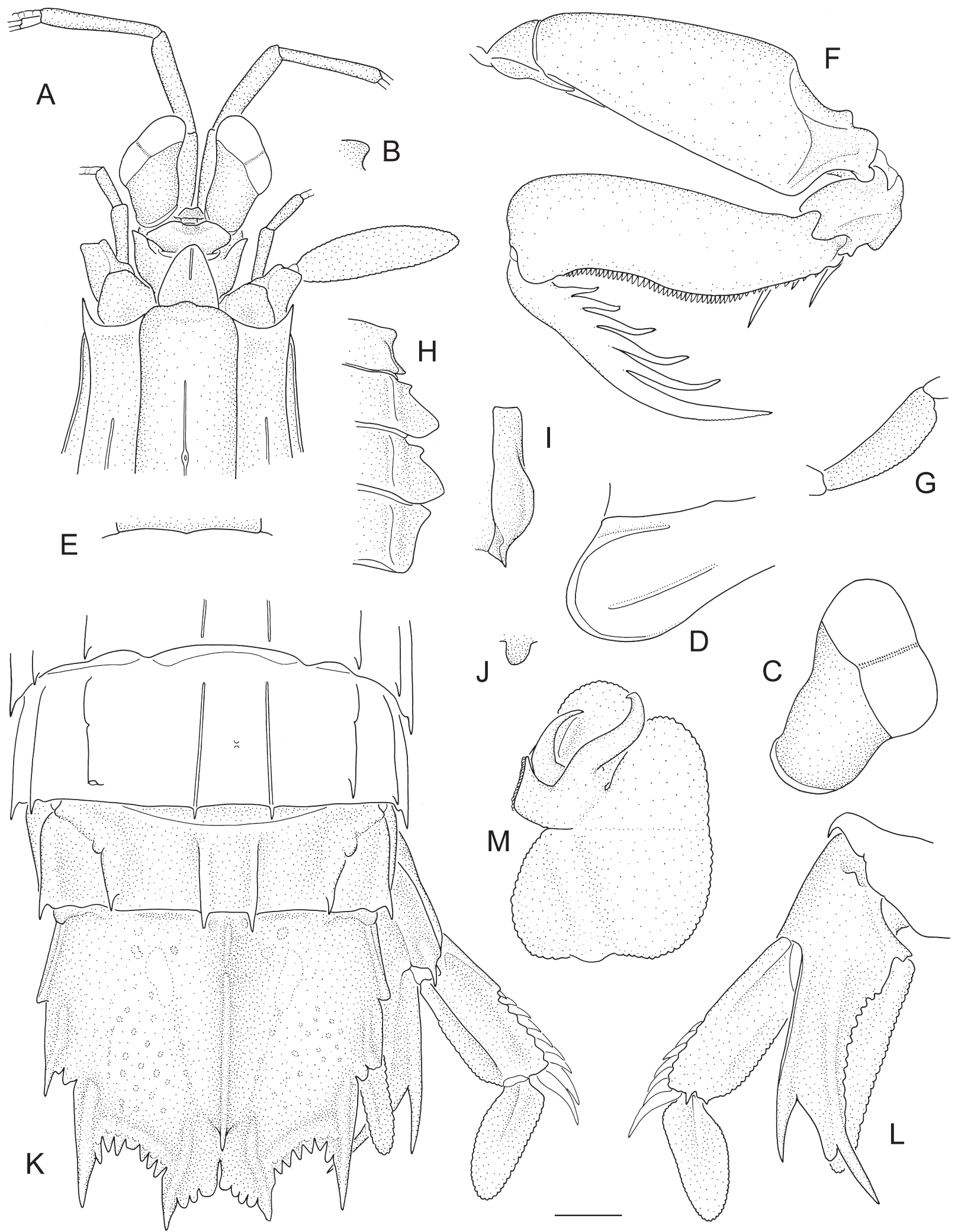

Figure 1. Michalisquilla parva (Bigelow, 1891) n. comb., male, TL 51 mm, Panama, Canal Zone, 4 April 1973 (USNM 150744). A, anterior cephalothorax, dorsal. B, right antennular somite dorsal process, lateral. C, right eye. D, right posterolateral margin of carapace. E, mid-posterior margin of carapace. F, right raptorial claw, lateral. G, right maxilliped 5 ischium. H, right thoracic somites 5-8, dorsal. I, right thoracic somite 5, lateral view. J, thoracic somite 8 sternal keel, right lateral. K, abdominal somites 4-6, telson and right uropod, dorsal. L, right uropod, ventral. M, right male pleopod 1 endopod, anterior. Scale: A, B, D-I, K, L = 2 mm; C, J, $\mathrm{M}=1 \mathrm{~mm}$. 
Rostral plate linguiform, as wide as or slightly longer than wide; lateral margins weakly carinate; apex rounded; dorsal surface with median carina anteriorly. Carapace anterior width $0.45-0.52 \mathrm{CL}$; anterolateral spines extending slightly beyond base of rostral plate; anterior bifurcation of median carina absent; posterior median projection obtuse.

Raptorial claw dactylus with 6 teeth; outer margin sinuous. Propodus distal margin unarmed. Carpus dorsal carina undivided, outer margin straight. Merus outer inferodistal angle blunt, rounded.

Mandibular palp absent or 1-3-articulate. Maxillipeds 1-5 each with epipod. Maxilliped 5 basal article with small, ventrally directed tooth; ischium ventral margin evenly rounded, unarmed.

Pereopod 1-3 basal articles unarmed; endopod articles fused.

Thoracic somites 6-8 submedian carinae subparallel. Thoracic somite 5 anterior lobe produced as a ventrally directed spine, not visible in dorsal aspect; lateral process posterior lobe obsolete, reduced to small, blunt, diagonal projection. Thoracic somites 6-7 lateral process anterior lobe short, blunt; posterior lobe large, broadly triangular, apex blunt. Thoracic somite 8 lateral process triangular, apex blunt; sternal keel rounded.

Male pleopod 1 endopod with petasma; posterior "endite" present; tube process curved, distinctly shorter than hook process; hook process without apical spine.

Abdominal somites $1-5$ submedian carinae slightly divergent posteriorly. Abdominal somite 6 submedian carinae parallel; with small ventrolateral spine anterior to uropodal articulation; sternum posterior margin unarmed. Abdominal carinae spined as follows: submedian 5-6, intermediate 4-6, lateral (3-4)5-6 (usually 4-6), marginal (1-2)3-5.

Telson slightly wider than long; apices of intermediate teeth extending posteriorly beyond base of submedian teeth; prelateral lobe as long as or slightly longer than margin of lateral tooth. Submedian, intermediate and lateral primary teeth each with smooth carina, that of lateral tooth not reaching anteriorly to distal end of prelateral lobe. Submedian denticles rounded; intermediate and lateral denticles blunt, triangular, each with low dorsal tubercle or swelling, often fusing in adult males; denticle formula: submedian 2-4, intermediate 6-8, lateral 1. Median carina interrupted proximally, with slender posterior spine. Dorsolateral surface with rows of shallow pits; supplementary longitudinal carinae absent. Telson postanal carina absent; ventrolateral carina extending almost to base of lateral tooth.

Uropodal protopod terminating in 2 slender spines; lobe on outer margin of inner spine narrower than to slightly wider than adjacent spine, proximal margin concave; inner margin of inner spine crenulate; minute blunt projection proximal to endopodal articulation.

Uropodal exopod proximal article with 9 or 10 movable spines on outer margin, distalmost reaching to midlength of distal article; distal margin with 2 ventral spines, outer spine longer. Exopod distal article as long as or shorter than proximal article.

Colour in life. Translucent with brown speckling and mottling. Carinae and grooves of carapace, body and telson dark-brown; lateral surfaces of thorax and abdomen pale pinkish. Telson with median carina and carinae of prelateral lobe primary teeth dark brown, those of submedian teeth also with dark red hue; anterior one-third of median carina with dark red hue and pair of small, clear spots; general surface pale brown, rows of dorsal pits dark brown. Uropodal protopod with ridges dull-yellow and brown-speckled; endopod with brown distal margins; exopod midrib and distal one-third black, extending onto mesial threefourths of distal article, remainder of distal exopod article yellow. Antennules dark-brown with yellowish peduncular articulations. Raptorial claw white overall; merus with dark brown speckling dorsally, pale yellowgreen meral depression. Pereopods 1-3 translucent, with sparse white and brown speckling.

Size. Male $(\mathrm{n}=24)$ TL $31-77 \mathrm{~mm}$, female $(\mathrm{n}=14)$ TL 35-57 mm. Hendrickx (2005) recorded specimens to TL $80 \mathrm{~mm}$.

Remarks. Michalisquilla parva comb. nov. is unusual among squillids in the variably segmented mandibular palp. Palp segments in $M$. parva are usually minute and relatively undifferentiated, but this is partially related to maturity. Individuals do not exceed TL $80 \mathrm{~mm}$ and appear mature at TL $38-44 \mathrm{~mm}$. In juveniles, the palp may be present as a bud, as two minute articles, absent (with an insertion usually present as in the lectotype), or a combination of these states. In adults, 
the palp is typically 2- or 3-articulate, though in the largest male examined, the palp is absent on one side (with an insertion) and unisegmental on the other; it is not clear if the missing palp was damaged or never present. In other respects, morphological variation is typical of other squillids: eye size and abdominal spination vary allometrically, with eyes proportionally larger in smaller specimens, and the marginal carinae of abdominal somites 1 or 1-2 unarmed in juveniles and small individuals up to TL $39 \mathrm{~mm}$, armed in all others.

The syntype series of $M$. parva consists of seven specimens (one female and six males). The largest and most intact specimen (an immature male, TL $42 \mathrm{~mm}$, USNM 18479) is herein selected as the lectotype to fix the identity of the species. The remaining syntypes become paralectotypes.

Distribution. Tropical eastern Pacific from the Gulf of California, Mexico, to Peru; intertidal to $132 \mathrm{~m}$, but usually 10-25 m (this study; Hendrickx and VázquezCureño, 1998).

\section{Vossquilla n.gen.}

Diagnosis. Eye large; cornea width less than $1 / 3 \mathrm{CL}$, strongly bilobed, distinctly broader than and set obliquely on stalk. Ocular scales separate. Dorsal integument variously pitted. Mandibular palp 3-articulate. Maxillipeds 1-4 each with epipod. Raptorial claw dactylus with 6 teeth, outer margin lacking basal notch; carpus dorsal carina undivided, smooth to irregular, not tuberculate; merus without outer inferodistal spine. Telson submedian teeth with fixed apices; prelateral lobe present; dorsolateral surface with curved rows of shallow pits; supplementary longitudinal carinae absent; ventral surface with short postanal carina. Carapace with anterolateral spines; median, intermediate, lateral, marginal and reflected marginal carinae present; median carina distinct, not interrupted at base of anterior bifurcation; branches of anterior bifurcation distinct, opening anterior to dorsal pit; posterolateral margin rounded. Thoracic somites 6-8 with distinct submedian and intermediate carinae. Thoracic somites 5-6 lateral processes bilobed. Thoracic somite 7 lateral process undivided. Abdominal somites 1-5 with distinct submedian, intermediate, lateral and marginal carinae; somite 6 with submedian, intermediate and lateral carinae. Abdominal somites 2 and 5 each with dark transverse dorsal patch. Uropodal protopod inner margin crenulate.

Etymology. Named for Harry Vos, "opa” of the first author, for encouragement with her studies. The name is a combination of Vos and the generic name Squilla. Gender feminine.

Type species. Squilla kempi Schmitt, 1931, by present designation and monotypy.

Remarks. Ahyong (2005) showed by phylogenetic analysis that $O$. kempi and the type species of Oratosquilla, Oratosquilla oratoria (De Haan, 1844), were not closely related. Oratosquilla kempi was instead sister to a large clade of genera of the Oratosquilla group that included Oratosquilla sensu stricto deeply nested within. Moreover, apart from the similarly uninterrupted anterior bifurcation of the median carina of the carapace, O. kempi differs from other species of Oratosquilla in important diagnostic features. Given the distant phylogenetic position of $O$. kempi and its aberrant morphology in comparison to other species assigned to Oratosquilla, a new genus is justified, herein named Vossquilla.

Vossquilla shares with Oratosquilla the uninterrupted anterior bifurcation of the median carina of the carapace, but differs in lacking an outer inferodistal spine on the merus of the raptorial claw, in having an irregular instead or distinctly tuberculate dorsal carina on the carpus of the raptorial claw, in having an undivided instead of distinctly bilobed lateral process of thoracic somite 7 , and in having dark dorsal pigment patches on abdominal somites 2 and 5 . Removal of Vossquilla kempi from Oratosquilla enables consistent diagnosis of the latter genus. Oratosquilla can now be clearly diagnosed by the combination of an uninterrupted anterior bifurcation of the median carina of the carapace that opens anterior to the dorsal pit, a tuberculate dorsal carina on the carpus and presence of an outer inferodistal spine on the merus of the raptorial claw, and the bilobed lateral processes of the thoracic somites 5-7.

Vossquilla superficially resembles Quollastria Ahyong, 2001 by lacking the outer inferodistal spine on the merus of the raptorial claw and the presence of 
dark dorsal markings on abdominal somites 2 and 5 . Vossquilla primarily differs from Quollastria, however, in having the anterior bifurcation of the median carina of the carapace entire instead of basally interrupted, and in having an undivided instead of strongly bilobed lateral process of thoracic somite 7. Additionally, $V$. kempi cannot be placed in either Miyakella Ahyong and Low, 2013 or Oratosquillina Manning, 1995, as both these genera, like Oratosquilla, possess a bilobed lateral processes on thoracic somite 7 and the inferodistal spine on the merus of the raptorial claw. Further, Oratosquillina has an interrupted anterior bifurcation of the median carina of the carapace, which, in $V$. kempi is uninterrupted, and in Miyakella is also uninterrupted but of a different form. In Miyakella, the branches of the anterior bifurcation open well behind the dorsal pit, rather than anterior to the pit (Ahyong, 2001, as Miyakea Manning, 1995).

\section{Vossquilla kempi (Schmitt, 1931) n. comb.}

$$
\text { (Fig. 2, 3B) }
$$

Chloridella kempi Schmitt, 1931: 135-140, 147, pl. 17 figs 6-9, pl. 18 figs. 10-11.

Squilla kempi. - Chopra, 1934: 31-35, figs. 3, 4. Holthuis, 1941: 254. — Liu, 1949: 41, 42, fig. 4a-b. Squilla oratoria. - Komai, 1927:315, fig. 1B (southern form). — Gravier, 1937: 183. — Komai, 1938: 266 (southern form). — Dawydoff, 1952: 145. [Not Squilla oratoria De Haan, 1844]

Squilla oratoria var. perpensa. - Gravier, 1937: 185, fig. 7. - Dawydoff, 1952: 145. [Not Squilla oratoria var. perpensa Kemp, 1911].

Oratosquilla kempi. — Manning, 1971: 4. - Blumstein, 1974: 119. - Dong et al., 1983: 82, 92, pl. 2 fig. 2. - Manning, 1995: 25 [list], 220, 221, figs. 135, 136h-j. - Sun et al., 1998: 22, fig. 8. — Wang and Liu, 1998: 133, 137, 139. - Ahyong et al. 1999: 47-49, fig. 6e. - Moosa, 2000: 411, 446, tab. 1. — Ahyong, 2005: 197. — Mitsuhashi and Takeda, 2006: 110 .

Type material. HOLOTYPE: USNM 61892, female (TL 120 mm), Amoy, China, coll. S.F. Light.

Other material examined. USNM 124774, female (TL 113 mm), Amoy, China, coll. S.F. Light; USNM
58744, 1 male (TL 113 mm), Foochow, China, coll. C.R. Kellogg; AM P99511, 1 male (TL $112 \mathrm{~mm}$ ), Kinmen, Taiwan Strait, 2424'N 118 24'E, 10-12 m, trawl, coll. R.Y. Lee, 26 June 2012; NTOU, 2 males (TL 94-107 mm), Kinmen, Taiwan Strait, 24²4’N $118^{\circ} 24^{\prime} \mathrm{E}, 10-12 \mathrm{~m}$, trawl, coll. R.Y. Lee, 26 June 2012; NTOU, 1 male (TL $28 \mathrm{~mm}$ ), 2 damaged females (TL 30-45 mm), Kinmen, Taiwan Strait, 242'N $118^{\circ} 24^{\prime} \mathrm{E}$, intertidal, coll. 25 June 2012; NTOU, 1 male (TL 104 mm), Pearl River estuary, Macau; AM P99510, 1 male (TL 56 mm), Pearl River estuary, Macau, 22 $33.4^{\prime} \mathrm{N} 113^{\circ} 48.1^{\prime}$ E, stn. 3, coll. K.H. Chu, 13 March 1993; USNM 127443, 1 female (TL 114 mm), Nagasaki, Kyushu, Japan, coll. J. B. Bernadon.

Description. Dorsal integument smooth, at most, weakly pitted.

Eye extending beyond midlength but not apex of antennular peduncle article 1; cornea strongly bilobed, set slightly obliquely on stalk; CI 308-500. Ophthalmic somite anterior margin rounded. Ocular scales truncate, separate.

Antennular peduncle length 0.84-0.97CL. Antennular somite dorsal processes trianguloid, directed anterolaterally, apices blunt. Antennal 2 scale length $0.52-0.63 \mathrm{CL}$.

Rostral plate subtrapezoid, slightly wider than long; lateral margins carinate; apex truncate to rounded; dorsal surface smooth or with short median tubercle or carina. Carapace anterior width $0.47-0.51 \mathrm{CL}$; anterolateral spines not extending beyond base of rostral plate; anterior bifurcation of median carina well-defined, about as long as distance between base of bifurcation and dorsal pit; posterior median projection obtuse.

Raptorial claw dactylus with 6 teeth; outer margin sinuous, with low proximal swelling. Propodus distal margin unarmed. Carpus dorsal carina irregular to weakly sinuous. Merus outer inferodistal angle blunt, obtuse, unarmed.

Mandibular palp 3-articulate. Maxillipeds 1-4 each with epipod. Maxilliped 5 basal article with small, ventrally directed tooth; ischium ventral margin evenly rounded, unarmed.

Pereopod 1-3 basal articles unarmed; endopod articles fused. 

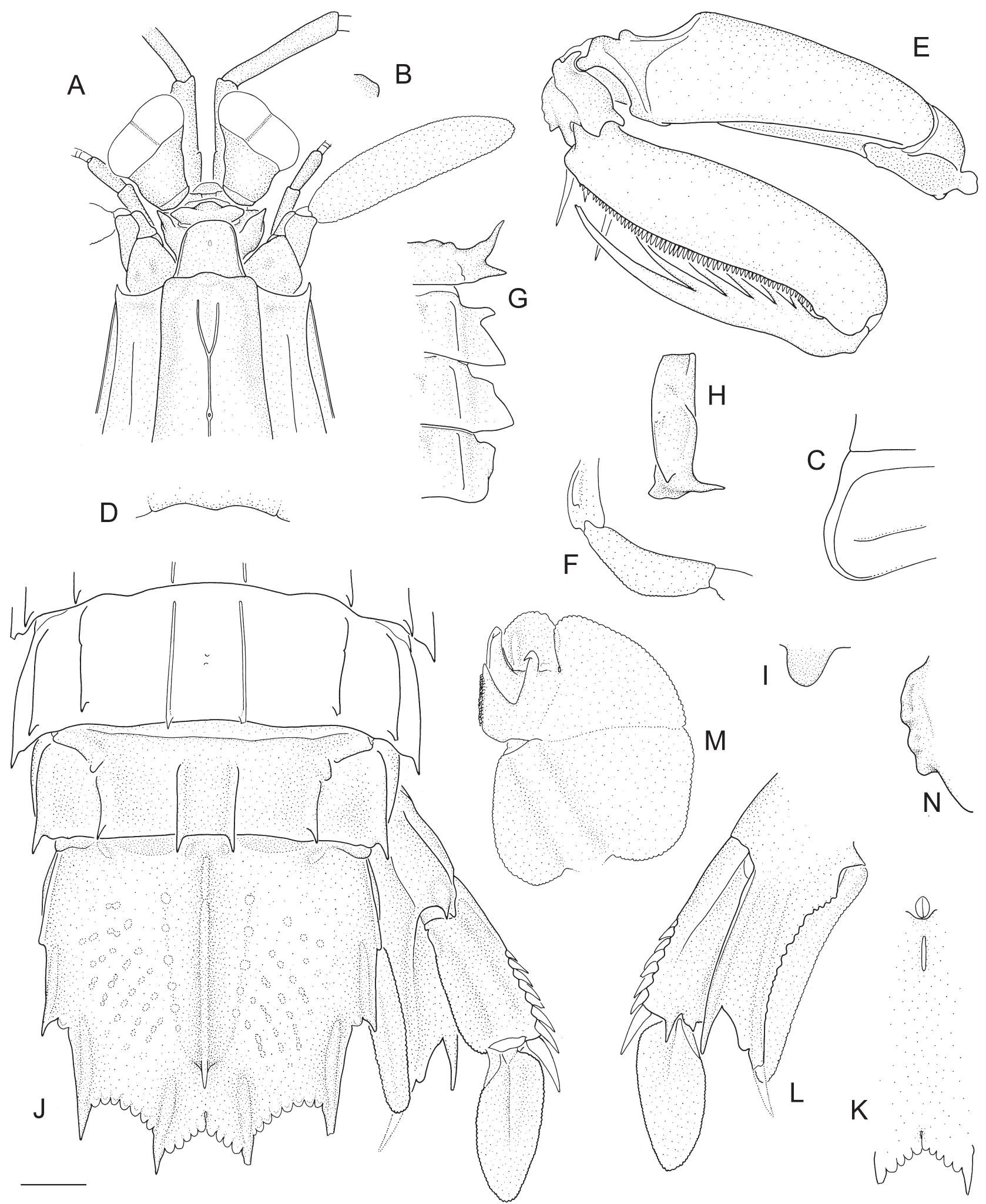

Figure 2. Vossquilla kempi (Schmitt, 1929) n. comb. A-K: male, TL 56 mm, Pearl River estuary, Macau, 13 March 1993 (AM P99510). M-N: male, TL 112 mm, Kinmen, Taiwan Strait (AM P99511). A, anterior cephalothorax, dorsal. B, right dorsal process of antennular somite, lateral. C, right posterolateral margin of carapace. D, mid-posterior margin of carapace. E, left raptorial claw, lateral. F, right maxilliped 5 basis and ischium. G, right thoracic somites 5-8, lateral. $\mathrm{H}$, right thoracic somite 5, lateral view. I, thoracic somite 8 sternal keel, right lateral. J, abdominal somites 4-6, telson and right uropod. dorsal. K, telson postanal keel, ventral. L, right uropod, ventral. M, right male pleopod 1 endopod, anterior. N, left raptorial claw, carpus dorsal carina, lateral view. Scale: A-H, $\mathrm{J}-\mathrm{N}=2 \mathrm{~mm} ; \mathrm{I}=1 \mathrm{~mm}$. 


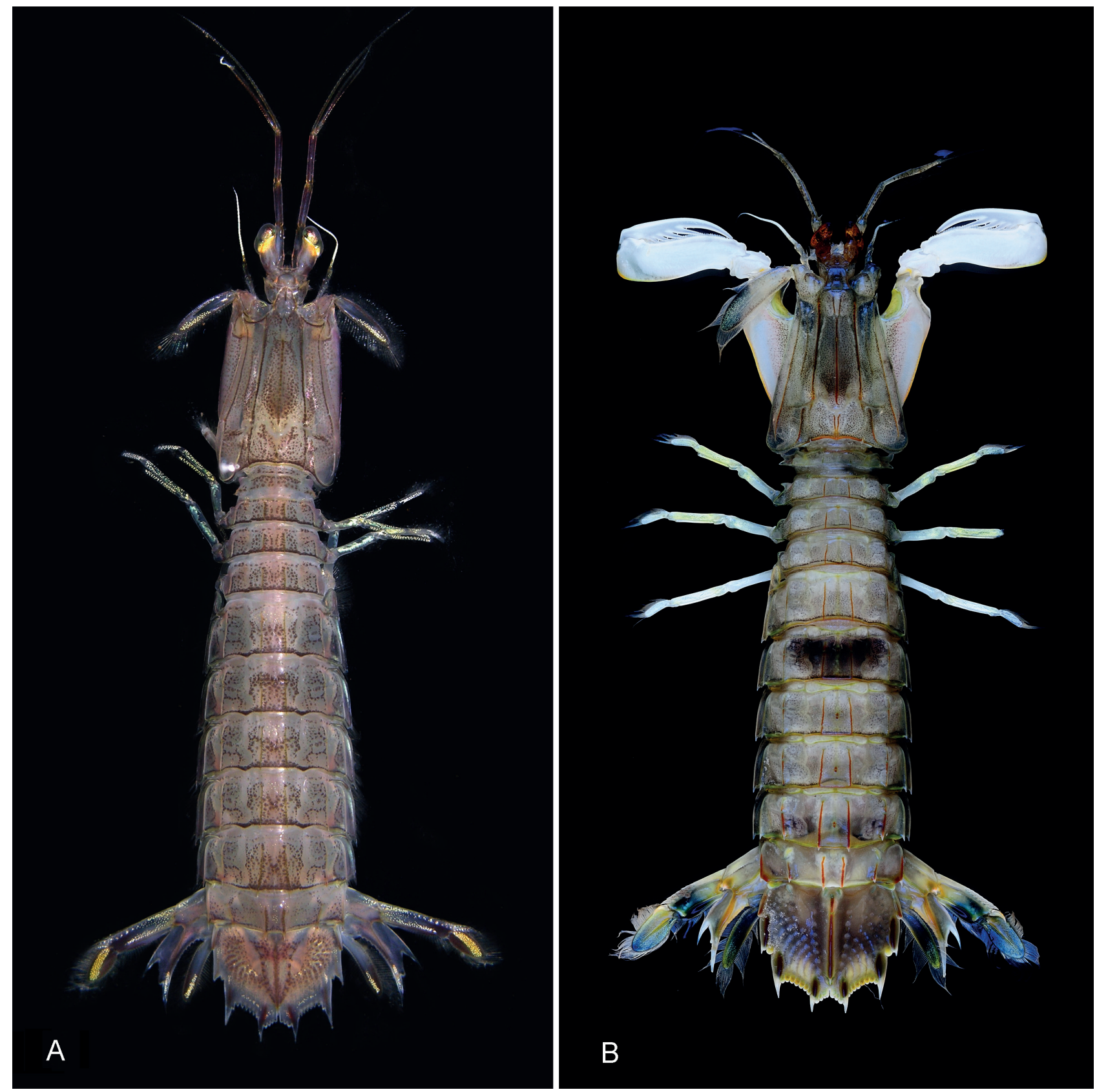

Figure 3. A, Michalisquilla parva (Bigelow, 1891) n. comb., male, TL 44 mm, Taboga Island, Panama (FLMNH UF 19464) (Photo: A. Anker). B, Vossquilla kempi (Schmitt, 1929) n. comb., male, TL 112 mm, Kinmen, Taiwan (AM P99511) (Photo: T.Y. Chan).

Thoracic somites $6-8$ submedian carinae weakly divergent. Thoracic somite 5 lateral process anterior lobe spiniform, recurved anterolaterally; posterior lobe short, sharp. Thoracic somite 6 lateral process anterior lobe slender, width about half length, less than one-third width of posterior lobe; posterior lobe large, triangular. Thoracic somite 7 lateral process broadly triangular, anteriorly margin straight or with low blunt swelling. Thoracic somite 8 lateral process triangular, apex blunt; sternal keel rounded.
Male pleopod 1 endopod with petasma; posterior "endite" present; tube process curved, distinctly longer than hook process; hook process without apical spine.

Abdominal somites $1-5$ submedian carinae subparallel to weakly divergent. Abdominal somite 6 with small ventrolateral spine anterior to uropodal articulation; sternum posterior margin unarmed. Abdominal carinae spined as follows: submedian 5-6, intermediate (3-4)5-6 (usually 4-6), lateral (2)3-6, marginal 1-5. 
Telson about as long as wide to slightly wider than long; apices of intermediate teeth extending posteriorly to base of submedian teeth; prelateral lobe slightly shorter to slightly longer than margin of lateral tooth. Submedian, intermediate and lateral primary teeth each with smooth carina, that of lateral tooth extending anteriorly slightly beyond distal end of prelateral lobe. Marginal denticles rounded, submedian and intermediate denticles each with low dorsal tubercle or swelling; denticle formula: submedian $2-4$, intermediate 6-8, lateral 1 . Median carina interrupted proximally, with tubercle below posterior spine. Dorsolateral surface with rows of shallow pits; supplementary longitudinal carinae absent. Telson ventral surface with short postanal carina, extending posteriorly to about proximal one-fourth of distance to between anal pore and posterior margin; ventrolateral carina extending almost to base of lateral tooth.

Uropodal protopod terminating in 2 slender spines; lobe on outer margin of inner spine narrower than adjacent spine, proximal margin concave; inner margin of inner spine crenulate; minute tooth proximal to endopodal articulation.

Uropodal exopod proximal article with 7 or 8 movable spines on outer margin, distalmost spine reaching to proximal one-third of distal article; distal margin with 2 ventral spines, outer longer. Exopod distal article slightly longer than proximal article.

Colour in life. Light grey-brown dorsally, darker middorsally. Carinae and grooves of carapace, submedian carinae, intermediate carinae, and abdominal somite 6 lateral carinae dark red. Mid-posterior margin of carapace yellow orange. Abdominal somite 2 and 5 with transverse black-brown patch between intermediate carinae, that of somite 5 on posterior half. Telson with median carina and prelateral lobe dark red; primary teeth with white tips and dark green carinae; telson surface with dark, irregular grey-green band across central one-third; submedian denticles white; intermediate and lateral denticles dull yellow-green. Uropodal protopod with whitish base colouration and dark yellow-green carinae, terminal spines white; endopod with speckled yellow distal half; exopod with white movable spines, with deep blue patch on distal half of proximal article; exopod distal segment diffuse blue in mesial half, diffuse white-yellow on lateral half. Antennules with black speckling. Raptorial claw white overall; merus with black and pink speckling dorsally, yellow-green meral depression and pale orange ventral outer margin; carpus white with yellow spot proximally; propodus with yellow disto-extensor margin and diffuse brown speckling; dactylus white. Pereopods 1-3 translucent white, yellowish distally.

Size. Male $(\mathrm{n}=6)$ TL $28-113 \mathrm{~mm}$, female $(\mathrm{n}=5)$ TL 30-120 mm. Sun et al. (1998) reported specimens to $149 \mathrm{~mm}$.

Remarks. The series of $V$. kempi examined is largely consistent, with variation in abdominal spination that is largely size related. The intermediate carinae on abdominal somite 4 are unarmed in the smallest specimens (male TL 28, female TL $30 \mathrm{~mm}$, NTOU), armed in all others. The prelateral lobes range from slightly shorter to slightly longer than the margins of the lateral teeth and the rostral plate may have a short median carina or dorsal tubercle, but is usually smooth dorsally; these variations appear unrelated to body size.

The dorsal carina of the raptorial claw carpus in $V$. kempi has been characterized as irregularly tuberculate as in O. oratoria (e.g., Manning, 1971; 1995), though the condition in $V$. kempi is better characterized as smooth or irregular, but not distinctly tuberculate; the condition varies allometrically, being smooth in the smallest specimens, becoming increasingly irregular with increasing body size. In Oratosquilla, the dorsal carina of the carpus of the raptorial claw is distinctly, albeit irregularly tuberculate in adults, and less pronounced in juveniles.

Distribution. Vietnam, China, Japan and for the first time from Taiwanese waters (Kinmen); intertidal to shallow subtidal depths.

\section{ACKNOWLEDGeMENTS}

We gratefully acknowledge Tin-Yam Chan (NTOU), Rafael Lemaitre and Karen Reed (USNM), and Gustav Paulay (FLMNH) for the loan of specimens. Rafael Lemaitre and Karen Reed are thanked for their hospitality to STA in Washington D.C.in 2013 and 2016, and Célio Magalhães for inviting this contribution in honor of the late Michael Türkay. Tin-Yam Chan and an anonymous reviewer are thanked for their constructive 
reviews of the manuscript. Colour images of V. kempi and M. parva were kindly shared by Tin-Yam Chan and Arthur Anker, respectively. This study was partially supported by an Australian Biological Resources Study (ABRS) National Taxonomy Research Grant (NTRGP; Grant No. CH215) to CVDW.

\section{RefERENCES}

Ahyong, S.T. 2001. Revision of the Australian stomatopod Crustacea. Records of the Australian Museum, Supplement 26: 1-326.

Ahyong, S.T. 2005. Phylogenetic analysis of the Squilloidea (Crustacea: Stomatopoda). Invertebrate Systematics, 19: 189-208.

Ahyong, S.T. 2012. The marine fauna of New Zealand: mantis shrimps (Crustacea: Stomatopoda). NIWA Biodiversity Memoir, 125: 1-111.

Ahyong, S.T. 2013. Stomatopoda collected primarily by the Philippine AURORA expedition (Crustacea, Squilloidea). p. 85-106. In: S.T. Ahyong; T.-Y. Chan; L. Corbari and P.K.L. Ng (eds), Tropical Deep-Sea Benthos, Volume 27. Paris, Muséum national d'Histoire naturelle (Mémoires du Muséum national d'Histoire naturelle, 204).

Ahyong, S.T.; Chu, K.H.; Chan, T.-Y. and Chen, Q.C. 1999. Stomatopoda of the Zhujiang estuary between Hong Kong and Macau. Crustaceana, 72: 37-54.

Ahyong, S.T. and Low, M.E.Y. 2013. Miyakella nom. nov., a replacement name for Miyakea Manning, 1995, (Crustacea: Stomatopoda: Squillidae), preoccupied by Miyakea Marumo, 1933 (Insecta: Lepidoptera: Crambidae). Zootaxa, 3616: 99-100.

Bigelow, R.P. 1891. Preliminary notes on some new species of Squilla. Johns Hopkins University Circulars, 10: 93-94.

Bigelow, R.P. 1894. Report on the Crustacea of the order Stomatopoda collected by the steamer Albatross between 1885 and 1891 and on other specimens in the U. S. National Museum. Proceedings of the United States National Museum, 17: 489-550, pls 420-422.

Blumstein, R. 1974. Stomatopod crustaceans from the Gulf of Tonkin with the description of new species. Crustaceana, 26: $113-126$

Chopra, B. 1934. On the stomatopod Crustacea collected by the Bengal Pilot Service off the mouth of the River Hughli, together with notes on some other forms. Records of the Indian Museum, 36: 17-43.

Dawydoff, C. 1952. Contribution a l'etude des invertebres de la faune marine benthique de l'lndochine. Bulletin Biologique de France et de Belgique, Supplement 37: 1-158, maps 1, 2.

De Haan, W. 1833-1850. Crustacea. In: Ph.F. von Siebold (ed), Fauna Japonica sive Descriptio Animalium, quae in Itinere per Japoniam, jussu et auspiciis superiorum, qui summum in India Batava Imperium tenent, suscepto, annis 1823-1830 collegit, notis, observationibus et adumbrationibus illustravit, pp. vii-xvii, i-xxi, ix-xvi, 1.243, pIs. A-J, L-Q 1.55, circ. tab. 2. Lugduni-Batavorum (Leiden), A. Arnz.
Dong, Y.M.; Chen, Y.S. and Huang, L.Q. 1983. Report on the stomatopods of the East China Sea. Donghai Marine Science, 1: 82-98.

Fabricius, J.C. 1787. Mantissa insectorum sistens eorum species nuper detectas: adjectis characteribus genericis, differentiis specificis, emendationibus, observationibus 1. Proft Hafniae.

Glassell, S.A. 1942. A new stomatopod Crustacean from the west coast of Mexico. Proceedings of the United States National Museum, 92: 53-55.

Gravier, Ch. 1937. Stomatopodes des côtes d'IndoChine. Annales de l'Institut océanographique, Monaco, new series, 17(3): 175-211.

Hendrickx, M.E. 1984. Distribution and abundance of stomatopods (Crustacea: Hoplocarida) in southern Sinaloa, Mexico. Revista de Biología Tropical, 32: 269-277.

Hendrickx, M.E. 2005. Estomatópodos del género Squilla (Hoplocarida: Stomatopoda: Squillidae) recolectados frente a la costa de Sinaloa, en el SE del golfo de California, México, en los cruceros CEEMEX C1-C2-C3. Ciencias Marinas, 31: 31-41.

Hendrickx, M.E. and Salgado-Barragán, J. 1991. Los estomatópodos (Crustacea: Hoplocarida) del Pacífico mexicano. Instituto de Ciencias del Mar y Limnología, Universidad Nacional Autónoma de México, Publicación Especial, 10: 1-200.

Hendrickx, M.E. and Salgado-Barragán, J. 1994. Stomatopods (Crustacea: Hoplocarida) collected off the coast of Sinaloa, Mexico, during the BIOCAPESS cruises IV, V and VI (August 1991, March and June 1982). Anales del Instituto de Biología, Universidad Nacional Autónoma de México, Serie Zoologia, 65: 217-231.

Hendrickx, M.E. and Salgado-Barragán, J. 2002. Stomatopoda. p. 373-400. In: J. Llorente Bosquets and J.J. Morrone (eds), Biodiversidad taxonomia y biogeografia de artrópodos de Mexico: Hacia una sintesis de su conocimiento, Vol. 3: 1-690.

Hendrickx, M.E. and Vázquez-Cureño, L.A. 1998. Composition and zoogeographical affinities of the stomatopod and decapod crustacean fauna collected during the Ceemex P4 cruise in the Gulf of Tehuantepec, Mexico. Bulletin de l'Institut Royal des Sciences Naturelles de Belgique, Biologie, 68: 135-144.

Holthuis, L.B. 1941. The Stomatopoda of the Snellius Expedition. Biological Results of the Snellius Expedition XII. Temminckia, 6: 241-294.

Kemp, S. 1911. Preliminary descriptions of new species and varieties of Crustacea Stomatopoda in the Indian Museum. Records of the Indian Museum, 6: 93-100.

Komai, T. 1927. Stomatopoda of Japan and adjacent localities. Memoirs of the College of Science, Kyoto Imperial University, series B, 3: 307-354, pls. 13, 14.

Komai, T. 1938. Stomatopoda occurring in the vicinity of Kii Peninsula. Annotationes Zoologicae Japonenses, 17 (Dr. A. Oka Jubilee Numbers): 264-275.

Latreille, P.A. 1802. Histoire naturelle, générale et particulière, des Crustacés et des Insectes 3. Paris, F. Dufart.

Linnaeus, C. 1758. Systema Naturae per Regna Tria Naturae, Secundum Classes, Ordines, Genera, Species, cum Characteribus, Differentiis, Synonymis, Locis. Edition 10, vol. 1: iii + 824 pp. Holmiae. 
Liu, J.Y. 1949. On some species of Squilla (Crustacea: Stomatopoda) from China coasts. Contributions from the Institute of Zoology, National Academy of Peiping, 5: 27-47, pls IV-VI.

Manning, R.B. 1968. A revision of the family Squillidae (Crustacea, Stomatopoda), with the description of eight new genera. Bulletin of Marine Science, 18: 105-142.

Manning, R.B. 1971. Keys to the species of Oratosquilla (Crustacea: Stomatopoda), with descriptions of two new species. Smithsonian Contributions to Zoology, 71: 1-16.

Manning, R.B. 1972a. Eastern Pacific expeditions of the New York Zoological Society. Stomatopod Crustacea. Zoologica, New York, 56: 95-113.

Manning, R.B. 1972b. Two new species of Pseudosquilla (Crustacea, Stomatopoda) from the Pacific Ocean. American Museum Novitates, 2484: 1-11.

Manning, R.B. 1974. Stomatopods collected by Th. Mortensen in the Eastern Pacific region (Crustacea, Stomatopoda). Steenstrupia, 3: 101-109.

Manning, R.B. 1995. Stomatopod Crustacea of Vietnam: the legacy of Raoul Serène. Crustacean Research, Special number 4: 1-339.

Manning, R.B. and Camp, D.K. 1983. Fennerosquilla, a new genus of stomatopod crustacean from the northwestern Atlantic. Proceedings of the Biological Society of Washington, 96: 317-322.

Manning, R.B. and Heard, R.W. 1997. Stomatopod crustaceans from the Carolinas and Georgia, southeastern United States. Gulf Research Reports, 9: 303-320 [dated 1996, published 1997].

Mitsuhashi, M. and Takeda, M. 2006. A list of mantis shrimps (Crustacea: Stomatopoda) in the collections of the Department of Zoology, the University Museum, the University of Tokyo. p. 107-113. In: R. Ueshima (ed), Catalogue of the Invertebrate Collection deposited in the Department of Zoology, The University Museum, The University of Tokyo. Tokyo, University of Tokyo. (Material Reports No. 62).

Moosa, M.K. 2000. Marine biodiversity of the South China Sea: a checklist of stomatopod Crustacea. Raffles Bulletin of Zoology, Supplement 8: 405-457.

Murillo-Bohórquez, C. and Alvarez-León, R. 2004. Nuevos registros y consideraciones biogeográficas de los estomatópodos (Hoplocarida: Stomatopoda) del Pacifico colombiano y comaparación con las especies del Caribe colombiano.p. 1-15. In: M.E. Hendrickx (ed), Contribuciones al Estudio de los Crustáceos del Pacifico Este. Mexico, Instituto de Ciencias del Mar y Limnología, UNAM.

Reaka, M.L. and Manning, R.B. 1980. The distributional ecology and zoogeographical relationships of stomatopod Crustacea from Pacific Costa Rica. Smithsonian Contributions to Marine Science, 7: 1-29

Schmitt, W.L. 1931. Chinese Stomatopoda collected by S. F. Light. Lingnan Science Journal, 8: 127-155, pls. 16-19. [Dated 1929, published 1931].

Schmitt, W.L. 1940. The stomatopods of the west coast of America, based on collections made by the Allan Hancock Expedition, 1933-38. Allan Hancock Pacific Expeditions, 5: 129-225.

Sun, X.; Wang, J. and Yang, S. 1998. Stomatopod Crustacea (1) Squillidae in the Beijing Natural History Museum. Memoirs of Beijing Natural History Museum, 56: 15-38.

Wang, Y. and Liu, R.-Y. 1998. Stomatopod fauna of the northern South China Sea and the Nansha Islands. Studies on the Marine Fauna and Flora and Biogeography of the Nansha Islands and Neighbouring Waters, 3: 131-142. 